\title{
REVIEW OF MACIEJ JOŃCA, ROMAN LAW. MIRABILIA, C.H. BECK, WARSZAWA 2020, PP. 506, ISBN 978-83-8158-443-2
}

\author{
Michat Lewandowski*
}

The year 2020 marked the publication of the book entitled Roman Law. Mirabilia, written by Prof. Maciej Jońca, by the renowned publishing house C.H. Beck. Prof. Maciej Jońca is Head of the Department of Roman law at the John Paul II Catholic University of Lublin and an art historian. Apart from that, he is an honorary member of the Academic Corporation Astrea Lublinensis (which I also happen to belong to).

Maciej Jońca is a recognizable scholar in the circle of Polish law historians. He is an author of five monographic studies and of over one hundred articles. Recently, his professional interests have been focused on the underscoring of the role of Roman law in the shaping of the cultural identity of the contemporary world. In his latest works he has proposed a provocative thesis that in the present times Roman law is often perceived as an "aunt" far advanced in years. Even though she may still exhibit considerable wisdom, she is already well past her prime. The "aunt" has something interesting to say occasionally, but there are few who would listen to her. However, as the author of Mirabilia argues, Roman law is now something more than a rigid academic discipline, as it comprises an integral part of our culture. It is our present DNA code. Roman law resembles a box of bricks, which can always be used to build something new. Trying to build a new legal system or a new codex, we almost always

* Michał Lewandowski, M.A., PhD Candidate in Law, KUL Doctoral School, The John Paul II Catholic University of Lublin; correspondence address: Al. Racławickie 14, 20-950, Lublin, Poland; e-mail: michal.lewandowski@kul.pl; https://orcid.org/ 0000-0002-8947-133X. 
use the same material and it is not all. There is also literature, art, popular culture etc. This is where Roman law is also to be found!

Mirabilia might be considered as a continuation of a previously published book entitled Roman Law. Marginalia. The accuracy of the ideas comprised in that study is best emphasized by the fact that in a short time it was reissued. It was already then that Maciej Jońca declared that he intended to make his texts lighter with a view to attracting a wider audience to the topic of Roman law, who otherwise would not be interested in strictly academic studies. "It was at that time that I over and over again realized that there existed such a plethora of issues and aspects that could be used as a prism for showing the intertwining of Roman law with the existing reality" he wrote then.

Prawo rzymskie. Mirabilia counts 505 pages including bibliography. It consists of 45 chapters, of which each is a separate essay. Undoubtedly, one of Jońca's skills as a writer is his ability to resort to a subtly provocative statement. He seems to have accidentally identified "the problem of Polish Roman studies", as he refers to it himself. The author claims that Polish authors have difficulties with reaching to a wider audience in Poland due to communication problems. In his opinion, Polish addressees should be offered texts written in a straightforward and uncomplicated way (due to the fact that the majority of people lack both profound knowledge and a willingness to put an effort into the reading process). The "Preface" also contains an important question: "What can Roman law offer to a Polish student of law?". The answer is simple: "An understanding that ius Romanum contains much more than just textbook mancipatio, interdicts or the scary Latin names of complaints may turn out to be a valuable experience". A considerable amount of time has passed since I took my exam in Roman law, but it seems to me that the above doubts deserve a moment of reflection.

One of the author's favourite sayings is this: "We are not only what we eat, but also what we look at". This principle has been effectively applied in the book, as each chapter is preceded by an illustration, which in itself is meant to speak to the reader. Despite the author's meticulous attention to the "aesthetics of the product", at times the reading of Jońca's book might be an arduous experience. While engaging in the reading of Mirabilia, we can participate in the author's bitter perception of reality. 
On several occasions we might be invited to share an entirely new perspective on life.

Indeed, the problem that has been present in the Polish academic world for some time is the difficulty of conveying the message, even though it is hardly an issue of contemporary times that a person from outside a specific field should be addressed in simple, understandable and interesting terms. It also has not really changed that popularization of knowledge is not particularly appreciated in Poland. As far as Roman law is concerned, it lies beyond doubt that an ever-going synthesis of all that has already been said by scholars previously sounds quite boring. Therefore, the approach proposed by Maciej Jońca in his Mirabilia (and before that in Marginalia) deserves appreciation.

Maciej Jońca points out that he was inspired by Antonio Guarino (1914-2015) who once said: "I merely think that by designating not-so-trivial a trend for developing Roman studies in contemporary times, I also made it reflect my sense of taste, by the fact that it was described half-jokingly". The above reference to both the scholar and his opinion is cunning and very accurate at the same time. Guarino is an icon of Italian Roman studies. This scholar was very quick in convincing the public that the secrets of the institutes of Roman law could be easily explained in the pages of the daily press and that esteemed journal Labeo could easily publish popular columns next to serious studies. Apparently Maciej Jońca wants to follow in Guarino's footsteps.

Each of the essays collected in Mirabilia is different and each is a closed entity, seemingly not connected with the other texts. Personally, I especially enjoyed a few of them. The first one is a study entitled "Where you are Gaius, I am Gaia - on Roman Marriage from a Different Perspective". At the beginning the author describes how Roman society perceived marriage. To our surprise, we learn that in the antique times, it was perceived by some as a necessary evil. Then we read: "At present, the essence of marriage is usually viewed through the prism of the teaching of the Church on the one hand and romantic comedies on the other. For the Church, marriage is a sacrament - a sacred and indissoluble one. Further, in romantic comedies action is constructed on the basis of the same well-rehearsed pattern" (p. 20). In this simple and elegant way, the author seems to be trying to say: "look, today we think in this way, 
but for the ancient people this or some other aspect of life was not so obvious or it looked entirely different".

The other essays which impressed me considerably include: "The die has been cast" (p. 10 et seq.), "On Roman bar with a grain of salt" (p. 65 et seq.), "Honour and written laws: some remarks on Polish academic corporations" (p. 339 et seq.), and "The capital of the non-practicing" (p. 463 et seq.). Let us briefly consider for the chapter "Honour and Written Laws: A Word on Polish Academic Corporations". In this essay the author (as mentioned above: an honorary member of the Polish Academic Corporation Astrea Lublinensis) describes in greater detail the way the academic corporations functioned, the way the Mensur or academic fencing looked like and also focuses on the concept of honour, being a good that was highly protected by the corporation customary law. He also pays attention to the way the state and also the Church tried to eliminate fencing duels from social life or limit them in such a way so as to minimize the risk of death of the contestants. The considerations are kept in a serious tone and then there is a dramatic turn. At the end, the reader is surprised with an amusing conclusion. "After some time had passed, the curator and fillister in one person received a shopping list for approval deemed necessary for carrying on with the activities of the corporation. It comprised schlägers and protective sleeves. For the non-initiated, the schläger is a duelling sword and protective sleeves were used to encase the forearm against cuts. No comment" (p. 351).

Another short essay that is also worth mentioning is the one entitled "The capital of the non-practicing" (p. 461 et seq.). It includes considerations on the fact that legal studies are most often chosen by those who are not-decided. The candidates declare that they want to become lawyers but they do not really know much about the specifics of this profession, nor do they know what their future professional life (possibly) will look like. Even though the persons mentioned in the book did not follow the legal profession as their career path after studies, in the conclusion we can read: "Law is worth studying. Not for the fact of studying itself, but for forming this unique-in-itself outlook on the world ... Legal education, even though a person may not choose to follow a career strictly related to legal professions, is usually more of a help than a hindrance in life". 
The above and all the other reflections offered by Maciej Jońca in his Mirabilia carry with themselves an important message. I do not claim that he is always right in his opinions, but he always presents his point of view in an original and intriguing way. Roman Law. Mirabilia is a book that has been written with a view to popularizing science and it fully accomplishes its purpose. Works such as Mirabilia are much needed as they make it easier to reach with scientific considerations and research results to wider audiences. A clueless reader requires some assistance as to the form in which the message is to be offered to him. Maciej Jońca managed to deal with this challenge. 